\title{
Agronomic performance and gaseous exchanges of the radish under saline stress and ascorbic acid application
}

\section{Rendimiento agronómico y cambios gaseosos de rábano bajo estrés salino y aplicación de ácido ascórbico}

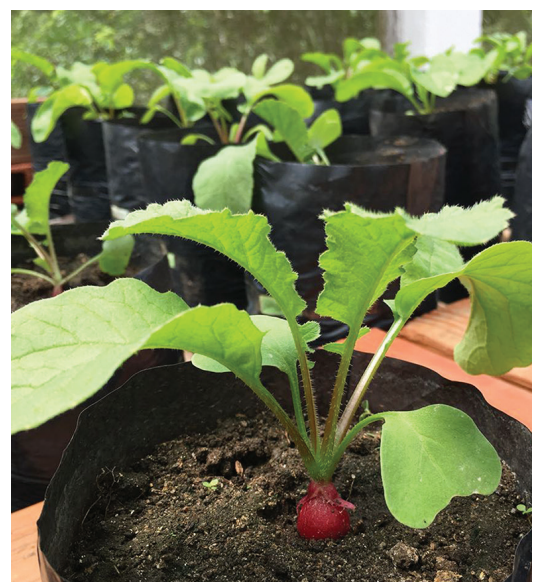

\section{YGOR HENRIQUE LEAL'1 \\ LEONARDO VIEIRA DE SOUSA ${ }^{1}$ \\ TOSHIK IARLEY DA SILVA, 5 \\ JOANA GOMES DE MOURA ${ }^{1}$ \\ ANA GABRIELA SOUSA BASÍLIO' \\ JOSÉ SEBASTIÃO DE MELO FILHO' \\ ANDERSON CARLOS DE MELO GONÇALVES ${ }^{3}$ \\ THIAGO JARDELINO DIAS ${ }^{4}$}

Radish subjected to saline stress and ascorbic acid.

Photo: L.V. Sousa

\begin{abstract}
The radish is a short-cycle vegetable that has excellent nutritional and medicinal properties. It is considered rustic, meaning it tolerates adverse conditions with the possibility of being irrigated with saline water, which creates stress. In this context, this study aimed to evaluate the effect of electrical conductivities in irrigation water and doses of ascorbic acid on the agronomic performance and gaseous exchanges of radishes. This experiment was carried out in a protected environment at the Agricultural Sciences Center of the Federal University of Paraíba, Areia, Paraíba (Brazil). The experiment design used randomized blocks with five doses of ascorbic acid $(0.0,0.29,1.0,1.71$ and $2.0 \mathrm{mM})$ and five electrical conductivities in the irrigation water $(0.5$, $1.3,3.25,5.2$ and $6.0 \mathrm{dS} \mathrm{m}^{-1}$ ), with four replicates. The growth, gas exchange and production were evaluated. The doses of ascorbic acid were not significant. The increase in the electrical conductivities of the irrigation water provided a reduction in the agronomic performance and gas exchanges, except for the net photosynthesis, water use efficiency and instantaneous carboxylation efficiency, which were not significant. There was a relationship between the net photosynthesis, transpiration, internal concentration of $\mathrm{CO}_{2}$ and water use efficiency and the stomatal conductance. The agronomic performance and gaseous exchanges of the radish culture were influenced by the salinity. The foliar application of ascorbic acid did not influence the agronomic yield and gaseous exchanges of the radishes at the tested doses.
\end{abstract}

Additional key words: Raphanus sativus L.; irrigation water; saline water; photosynthetic activity; antioxidant.

Federal University of Paraíba, Department of Agrarian Sciences and Environmental Sciences, Areia (Brazil). ORCID Leal, Y.E.: 0000-0001-7155-3524; ORCID Vieira de Sousa, L.: 0000-0001-5846-3399; Gomes de Moura, J.: 0000-00024389-2956; Sousa Basílio, A.G.: 0000-0003-2873-8202; ORCID Melo Filho, J.S.: 0000-0003-3005-2795

2 Federal University of Viçosa, Department of Plant Science, Viçosa (Brazil). ORCID Da Silva, T.I.: 0000-0003-0704-2046

3 Federal University of Roraima, Department of Plant Science, Boa Vista (Brazil). ORCID Gonçalves, A.C.M.: 00000003-4151-1192

${ }^{4}$ Federal University of Paraíba, Department of Agriculture, Bananeiras (Brazil). Dias, T.J.: 0000-0002-7843-6184

5 Corresponding author. iarley.toshik@gmail.com 


\section{RESUMEN}

El rábano es una hortaliza de ciclo corto que presenta excelentes propiedades nutricionales y medicinales. Es considerada rústica, pues tolera condiciones adversas, con énfasis en la posibilidad de poder ser regado con agua salada, principalmente cuando se asocia a la atenuación del estrés causado. En este contexto, el presente trabajo tuvo como objetivo evaluar el efecto de conductividades eléctricas del agua de riego y de dosis de ácido ascórbico en el desempeño agronómico e intercambios gaseosos del rábano. El experimento fue conducido en un ambiente protegido, en el Centro de Ciencias Agrarias de la Universidad Federal de Paraíba, Areia, Paraíba (Brasil). El diseño experimental fue hecho en bloques aleatorizados, con cinco dosis de ácido ascórbico $(0,0 ; 0,29 ; 1,0 ; 1,71$ y $2,0 \mathrm{mM})$ y cinco conductividades eléctricas del agua de riego $\left(0,5 ; 1,3 ; 3,25 ; 5,2\right.$ y $\left.6,0 \mathrm{dS} \mathrm{m}^{-1}\right)$, con cuatro repeticiones. El crecimiento, los intercambios gaseosos y la producción fueron evaluados. Las dosis de ácido ascórbico no fueron significativas. El aumento de las conductividades eléctricas del agua de riego disminuyó el desempeño agronómico y los intercambios gaseosos, salvo para fotosíntesis neta, eficiencia del uso del agua y eficiencia instantánea de carboxilación, que no presentaran importancia. Hubo una relación de la fotosíntesis neta, transpiración, concentración interna de $\mathrm{CO}_{2}$ y eficiencia del uso del agua con la conductancia estomática. El desempeño agronómico y el intercambio gaseoso del cultivo de rábano son influenciados por la salinidad. La aplicación de ácido ascórbico a través de la hoja no influye en el rendimiento agronómico y los intercambios gaseosos del rábano a las dosis probadas.

Palabras clave adicionales: Raphanus sativus; agua de riego; agua salada; actividad fotosintética; antioxidante.

Received for publication: 10-05-18 Accepted for publication: 29-03-2019

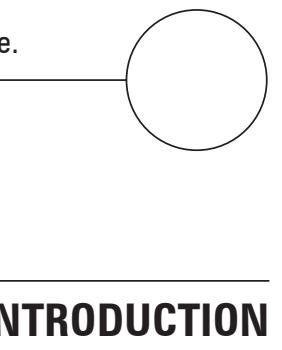

The radish (Raphanus sativus L.) is a small vegetable that tolerates adverse conditions. Its origin lies in the Mediterranean region, and it belongs to the Brassicaceae family, which contains broccoli, cabbage, cauliflower and cabbage; however, the tuberous root is the part that is consumed, which has a reddish external color and a white flesh with a spicy flavor (Lanna et al., 2018).

Radish production has been stimulated because of the fact that it presents high rusticity with a short cycle crop, which means less time for harvesting, providing a fast economic return and making it a great alternative for intercropping with long cycle crops. It is appreciated for its vitamins A, B1, B2 and C, potassium, calcium, phosphorus and sulfur contents, conferring excellent medicinal properties, such as an antioxidant action, natural expectorant and coadjuvant of the digestive system (Oliveira et al. 2010; Cunha et al., 2017).

Radish crops are commonly irrigated, where the use of salt water is often the only alternative for production because quality water is increasingly scarce, especially in regions with high temperatures and low rainfall, resulting in increased salt concentration in the water (Lima et al., 2017). Among the abiotic stresses, saline is the most harmful to crop growth and productivity (Santos et al., 2012), reducing the osmotic potential of the soil solution, which can cause water deficits in plants and consequently reduce or inhibit the absorption of nutrients as a result of an ionic imbalance in the soil solution, causing phytotoxicity mainly through sodium and chloride ions (Eschemback et al., 2014).

In addition, saline stress can also cause plant dehydration as a result of a high salt uptake, meaning plants cannot compartmentalize and raising the concentration of these salts within plants (Parihar et al., 2015). In this sense, plants need greater energy expenditure to perform their vital functions, affecting growth, development and consequently productivity (Silva et al., 2012).

One of the mitigating methods for saline stress in plants is the application of ascorbic acid, which is an important antioxidant, protecting plants from oxidative stress, especially when caused by saline stress (Gul et al., 2015). It also helps the enzyme ascorbate peroxidase (APX) convert hydrogen peroxide $\left(\mathrm{H}_{2} \mathrm{O}_{2}\right)$, which is a reactive oxygen species (EROS) produced 
in greater amounts in plants under stress that affects cellular homeostasis, playing a key role in tolerance to salinity and influencing stomatal opening, besides being easily absorbed by plants after foliar applications (Hameed et al., 2015).

In this context, it is necessary to establish the dose that provides the best attenuation results under saline stress in radish cultures. The aim of this study was to evaluate the effect of different electrical conductivities of irrigation water and ascorbic acid doses on agronomic performance and gaseous exchanges of the radish ( $R$. sativus).

\section{MATERIAL AND METHODS}

This experiment was carried out from October to November, 2017, in a protected environment (greenhouse), in the Department of Plant Science and Environmental Sciences of the Center of Agricultural Sciences of the Federal University of Paraíba (UFPB), in the city of Areia, PB (Brazil). The soil used in the experiment was an Oxisol (Tab. 1), collected from a 0-20 $\mathrm{cm}$ depth layer.

This experiment was carried out in a randomized complete block design, composite central box experiment (Bortoluzzi and Alvarez, 1997), in a $5 \times 5$ factorial scheme, with four replications for five doses of ascorbic acid (AA - 0.0, 0.29, 1.0, 1.71 and $2.0 \mathrm{mM}$ ) and five electrical conductivities in the irrigation water $\left(\mathrm{ECw}-0.5,1.3,3.25,5.2\right.$ and $\left.6.0 \mathrm{dS} \mathrm{m}^{-1}\right)$. A treatment that was irrigated with $0.5 \mathrm{dS} \mathrm{m}^{-1}$ water and no ascorbic acid was used to determine the irrigation depth using drainage lysimetry. The experiment plots were represented by plastic bag for the seedlings, with a capacity of $3.0 \mathrm{dm}^{3}$. Margaret Queen Kobayashi hybrid radish seeds were used, sowing five seeds in each plastic bag at a depth of $2 \mathrm{~cm}$. On the 15 day after sowing (DAS), thinning was carried out, leaving the plants more vigorous.

The lowest salinity water $\left(0.5 \mathrm{dS} \mathrm{m}^{-1}\right)$ came from the UFPB's supply system. A mixture of salts of $\mathrm{NaCl}$,
$\mathrm{CaCl}_{2} \cdot 2 \mathrm{H}_{2} \mathrm{O}$ and $\mathrm{MgCl}_{2} \cdot 6 \mathrm{H}_{2} \mathrm{O}$ and $0.5 \mathrm{dS} \mathrm{m} \mathrm{m}^{-1}$ water were added to the water with the highest salinity (1.3, 3.25, 5.2 and $\left.6.0 \mathrm{dS} \mathrm{m}^{-1}\right)$, maintaining an equivalent ratio of 7:2:1 (Medeiros, 1992), measuring the ECW with a portable conductivity meter. Throughout the experiment, the plants were irrigated with the ECw that was established for each treatment, with irrigation management done using drainage lisimetry.

Foliar applications of ascorbic acid were carried out at 19 DAS with the aid of an atomizer containing the doses of ascorbic acid and the adjuvant (Tween ${ }^{\circledR} 80$ ) at a concentration of $0.0002 \%$ of the syrup.

At 35 DAS, the following variables were analyzed: leaf number (LN), counting all the leaves of each plant; stem diameter (SD), using a digital caliper; leaf area (LA), with the aid of a graduated ruler to record the length and width dimensions of the leaves and then the equation $L A=C^{*} L^{*} f$, from Benincasa (2003), where $L A$ refers to leaf area; $C$ leaf length in $\mathrm{cm}$; $L$ leaf width in $\mathrm{cm}$; and $f$ correction factor for radish $=0.57$; specific leaf area (SLA), according to Witkowski and Lamont (1991), where SLA = leaf area * dry leaf weight; root dry mass (RDM) and tuber dry mass (TDM), determined on a scale with a precision of $0.001 \mathrm{~g}$. In order to obtain the dry root and tuber masses, the material was packed in paper bags and oven dried at a temperature of $65^{\circ} \mathrm{C}$ until reaching constant weight.

The gaseous exchange determinations were carried out at 34 DAS, using an infrared gas analyzer (IRGA, LI-COR - model LI-6400XT Portable Photosynthesis System) from 9:00 am to 10:00 am. The following characteristics were measured: net $\mathrm{CO}_{2}$ assimilation (A - $\mu \mathrm{mol} \mathrm{CO} \mathrm{Cm}^{-2} \mathrm{~s}^{-1}$ ); stomatal conductance (gs - $\mathrm{mol}$ $\mathrm{H}_{2} \mathrm{O} \mathrm{m} \mathrm{m}^{-2} \mathrm{~s}^{-1}$ ); internal $\mathrm{CO}_{2}$ concentration ( $\mathrm{Ci}-\mathrm{mmol}$ $\left.\mathrm{CO}_{2} \mathrm{~m}^{-2} \mathrm{~s}^{-1}\right)$; transpiration rate $\left(\mathrm{E}-\mathrm{mmol} \mathrm{H} \mathrm{O} \mathrm{m}^{-2} \mathrm{~s}^{-1}\right)$; water use efficiency (WUE - A/E) and vapor pressure deficit (VPD - kPa).

Based on the accumulation of total dry matter and leaf area, the growth variables were determined

Table 1. Results of the chemical soil analysis used in this experiment.

\begin{tabular}{|c|c|c|c|c|c|c|c|c|c|c|c|}
\hline $\mathrm{pH}$ & OM & P & $\mathrm{K}^{+}$ & $\mathrm{Na}^{+}$ & $\mathrm{Ca}^{2+}$ & $\mathrm{Mg}^{2+}$ & $\mathrm{Al}^{3+}$ & $\begin{array}{l}\mathrm{H}^{+}+ \\
\mathrm{Al}^{3+}\end{array}$ & SB & CEC & V \\
\hline $\mathrm{H}_{2} \mathrm{O}$ & $\%$ & \multicolumn{2}{|c|}{$--\mathrm{mg} \mathrm{dm}^{-3}--$} & \multicolumn{7}{|c|}{--- $\mathrm{cmol}_{\mathrm{c}} \mathrm{dm}^{-3}$} & $\%$ \\
\hline 6.20 & 2.48 & 24.85 & 78.42 & 0.07 & 3.90 & 1.90 & 0.00 & 2.43 & 6.07 & 8.50 & 71.46 \\
\hline
\end{tabular}

OM: organic matter; SB: sum of bases; CEC: cation exchange capacity; V: saturation by bases. 
according to Benincasa (2003), corresponding to the relative growth rate, $\mathrm{RGR}\left(\mathrm{g} \mathrm{g}^{-1} \mathrm{~d}^{-1}\right)$, using the equation RGR $=(\operatorname{LnW} 2-\mathrm{LnW} 1) *(\mathrm{~T} 2-\mathrm{T} 1)-1$, where LnW1 and LnW2 are the variation of the neperian logarithm of the dry mass between two periods, and $\mathrm{T} 1$ and $\mathrm{T} 2$ are the time variation between the periods. The leaf area ratio, LAR $\left(\mathrm{cm}^{2} \mathrm{~g}^{-1}\right)$, was determined using the equation $\mathrm{LAR}=\mathrm{L} * \mathrm{~W}-1$, where $\mathrm{L}$ is the leaf area and $\mathrm{W}$ the total dry mass of the plant. The data obtained in the evaluations of the experiment were submitted to analysis of variance and regression using SAS University software (Cody, 2015).

\section{RESULTS AND DISCUSSION}

According to the analysis of variance, there was no interaction between the ascorbic acid (AA) and the electrical conductivities of the irrigation water (Ecw); also, there was no effect between the doses of ascorbic acid for both agronomic performance variables for the variables of gas exchange, probably because radish plants demand higher doses.
However, a difference was observed between the ECW applications in the radish plants. It was observed that, as the ECw increased (Fig. 1, 2 and 3), the values of the agronomic performance variables (leaf number, stem diameter, leaf area, specific leaf area, tuber fresh mass, root dry mass, relative growth rate and leaf area ratio) deceased.

Saline stress is the most damaging to crop growth and productivity among the abiotic stresses (Santos et al., 2012), causing reductions in the osmotic potential of the soil solution and consequently water deficits in plants, promoting a reduction or inhibition of the absorption of some nutrients as a result of an ionic imbalance of the soil solution and phytotoxicity, especially with sodium and chloride ions (Eschemback et al., 2014).

Several harmful effects caused by saline stress on plants can be related to the results obtained in the present study, where the higher salt concentrations intensified the negative reflexes in the development of the radish plants. Sousa et al. (2016a), evaluating

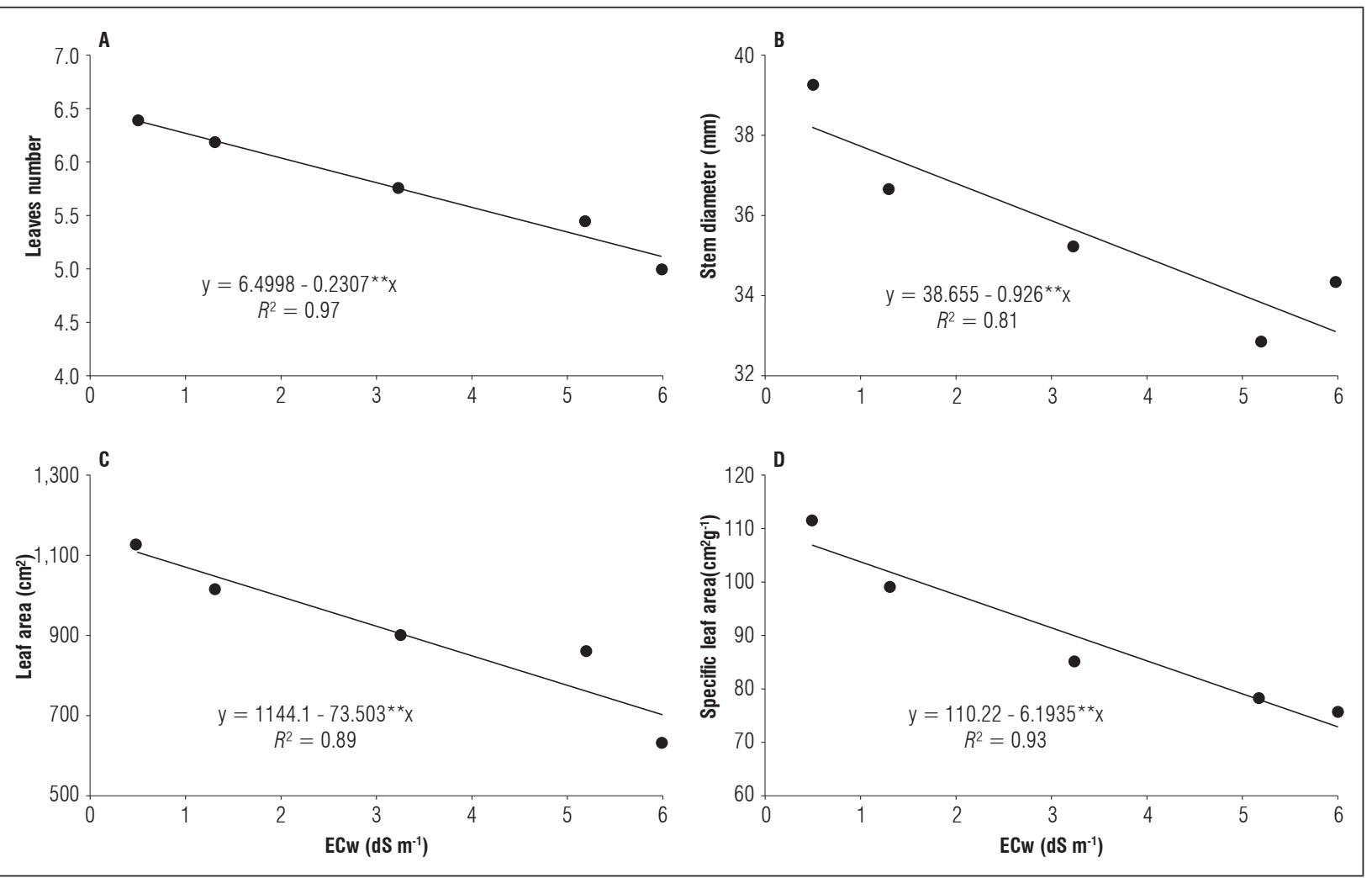

Figure 1. Leaf number (A), stem diameter (B), leaf area (C) and specific leaf area (D) of the radish plants as a function of the different electrical conductivities of the irrigation water (ECw). 
the growth and productive performance of radish plants under different Ecw applications, observed results similar to those of the present study, where irrigation water with a higher electrical conductivity provided lower values for leaf area, shoot dry mass, fruit diameter, average fruit mass and productivity.

Given the variable number of leaves (Fig. 1A), it was notable that, in the lowest $\left(0.5 \mathrm{dS} \mathrm{m}^{-1}\right)$ and highest $\left(6.0 \mathrm{dS} \mathrm{m} \mathrm{m}^{-1}\right)$ Ecw applications, there were 6.4 and 5.1 leaves per plant, respectively, corresponding to a reduction of $20.3 \%$. Similarly, Oliveira (2010), also working with salinity in a radish culture, obtained 6.9 leaves with the lowest Ecw application $(0.5 \mathrm{dS}$ $\mathrm{m}^{-1}$ ) and 3.6 leaves with $5.0 \mathrm{dS} \mathrm{m} \mathrm{m}^{-1}$, corresponding to a reduction of $47.6 \%$, well above the present study even though the maximum ECW value was lower than that applied by this author. Osmotic imbalances, damage from oxygen reactive species (ROS) and ionic toxicity are the main characteristics observed in radish plants under saline stress (Sun et al., 2016).

As for stem diameter (Fig. 1B), a reduction of $13.4 \%$ was observed, with the respective values of 38.2 and $33.1 \mathrm{~mm}$ for the ECw amplitude $\left(0.5\right.$ and $\left.6.0 \mathrm{dS} \mathrm{m}^{-1}\right)$. Santos et al. (2016), evaluating the growth and phytomass of beet plants under different ECw applications (1.0 to $5.0 \mathrm{dS} \mathrm{m}^{-1}$ ), observed that, up to an ECw of $3.0 \mathrm{dS} \mathrm{m}^{-1}$, the stem diameter increased, with a maximum value corresponding to $33 \mathrm{~mm}$, with a decrease in stem diameter values beyond this $\mathrm{ECw}$ value.

The leaf area of the radish plants (Fig. 1C) varied negatively between the lowest and highest ECw applications $\left(0.5\right.$ and $6.0 \mathrm{dS} \mathrm{m}^{-1}$ ), and the respective values were 1107.4 and $703.1 \mathrm{~cm}^{2}$, corresponding to a reduction of $36.5 \%$. Oliveira et al. (2012) reported that an ECw of $2.0 \mathrm{dS} \mathrm{m}^{-1}$ resulted in the highest leaf area value $\left(497.2 \mathrm{~cm}^{2}\right)$, while the highest ECW $(10.0$

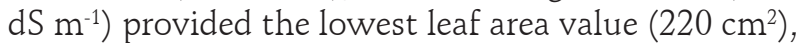
corresponding to a decrease of $55.75 \%$ for the radish culture.

When evaluating the growth and productivity of radish plants under different irrigation water salinities, $0.8,1.5,3.0$ and $4.5 \mathrm{dS} \mathrm{m}^{-1}$, Sousa et al. (2016a) obtained a leaf area of 127 and $64.1 \mathrm{~cm}^{2}$ in the smallest and largest ECW applications, corresponding to a decrease of $49.5 \%$ in the leaf area, well above that of the present study. Srivastava et al. (2016), working with two varieties of radish plants under different concentrations of $\mathrm{NaCl}(0,50,100,150$ and $200 \mathrm{mM})$, also observed the same tendency for the variables leaf area, root and stem length and total biomass, where the higher salinity water provided lower values.

Saline stress alters the osmotic potential of the soil solution, which can cause water deficits in plants, which consequently reduce nutrient absorption, necessitating a higher energy expenditure and affecting growth, development and productivity (Silva et al., 2012). The results of this study evidenced a strong relationship, where the negative effect of one variable interfered, directly and negatively, with the others, explaining their similar behavior.

The highest leaf area $\left(1107.35 \mathrm{~cm}^{2} \mathrm{~g}^{-1}\right)$ was observed in the lowest ECW application $\left(0.5 \mathrm{dS} \mathrm{m}^{-1}\right)$, and the lowest specific leaf area $\left(703.08 \mathrm{~cm}^{2} \mathrm{~g}^{-1}\right)$ was seen

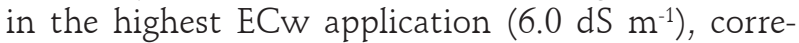
sponding to a decrease of $36.5 \%$. This negative effect was due to the inhibition of the development of the
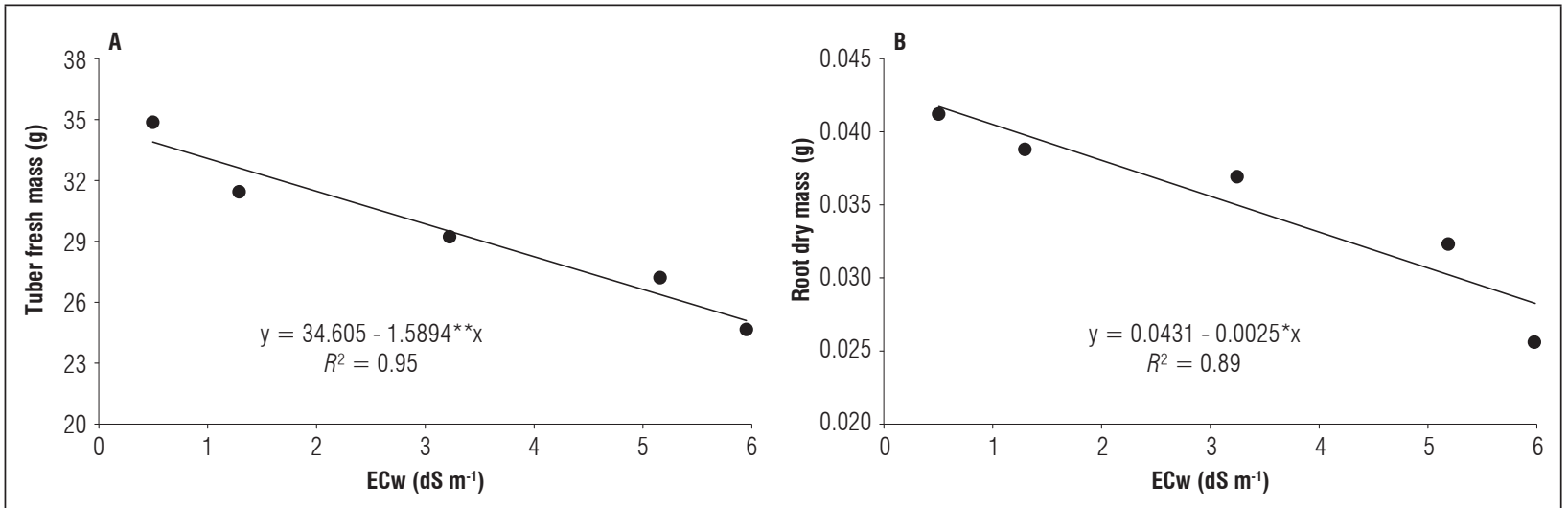

Figure 2. Fresh grass mass (A) and root dry mass $(B)$ of the radish plants as a function of the different electrical conductivities of the irrigation water (ECw). 
plants in the higher salt concentrations, reducing the leaf area and dry mass. Santos et al. (2017) also observed a decreasing behavior for specific leaf area in radish plants.

The tuber fresh mass and the root dry mass (Fig. 2A and B) also presented an inversely proportional behavior to the increase in the ECW applications, where the extreme results were 33.81 and $25.07 \mathrm{~g}$ for tuber fresh mass and $\mathrm{s}$ of 0.042 and $0.028 \mathrm{~g}$ for dry matter mas. for the lowest and highest ECw applications $\left(0.5\right.$ and $\left.6.0 \mathrm{dS} \mathrm{m} \mathrm{m}^{-1}\right)$, corresponding to reductions of 74.15 and $66.67 \%$, respectively. The same behavior was observed by Brunes et al. (2013) who worked with two rice cultivars, showing a decrease in the dry mass of the roots and shoots as the ECW increased.

Sousa et al. (2016a), studying salinity in a radish culture, observed a fresh mass of 9.11 and $2.13 \mathrm{~g}$ respectively for an ECw of 0.8 and $4.5 \mathrm{dS} \mathrm{m}^{-1}$, values well below those of the present study, but with similar behaviors and percentages of reduction (76.62\%). Similarly, Oliveira et al. (2010), in a similar study, obtained inferior results for tuber fresh mass (19.07 and $9.12 \mathrm{~g}$ ) using water conductivity (ECW) that varied between 0.5 and $5.0 \mathrm{dS} \mathrm{m}^{-1}$ in the radish culture.

These results were due to the high absorption of salts, which the plants could not compartmentalize, increasing the concentration of these salts in the interior and causing dehydration and consequently a reduction of the fresh mass (Parihar et al., 2015). According to Mekawy et al. (2015), another possible explanation would be the different responses of the evaluated cultivars since each genetic material has different tolerances and mechanisms under conditions of saline stress, where the one used in the present study stood out for these authors.

The leaf area ratio (Fig. 3A) was also affected by the increasing salinity, where the highest and lowest values (920.70 and $692.51 \mathrm{dm}^{2} \mathrm{~g}^{-1}$ ) were obtained with the ECw extremes $\left(0.5\right.$ and $\left.6.0 \mathrm{dS} \mathrm{m}^{-1}\right)$, as well as the relative growth rate $\left(0.036\right.$ and $\left.0.024 \mathrm{~g} \mathrm{~g}^{-1} \mathrm{~d}^{-1}\right)$ (Fig. 3B).

Santos et al. (2014) observed the same behavior using irrigation waters with an ECw up to $4.0 \mathrm{dS} \mathrm{m}^{-1}$ in leguminous species, where waters with a higher $\mathrm{ECw}$ yielded lower results for the relative growth rate. The $\mathrm{ECw}$ increase also negatively affected the stomatal conductance (gs), the internal $\mathrm{CO}_{2}$ concentration (Ci) and the transpiration (E) at an ECw of 3.88, 4.34

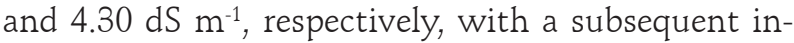
crease in these variables at an ECw of $6.0 \mathrm{dS} \mathrm{m}^{-1}$ (Fig. 4). The reductions of these variables corresponded to 150, 20.3 and $60.6 \%$, respectively. The net photosynthesis showed no significant effect; therefore, it was not shown in the graphs.

Such results can be justified by the presence of salts in the soil solution, reducing the water absorption capacity of the plants and causing water stress as the saline concentration increased because, in this situation, the main defense mechanism of the plants includes A, gs, Ci and E (Parihar et al., 2015), which is why these variables are directly related and presented similar behaviors, negatively affecting the photosynthetic apparatus of the radish and, consequently, yield.
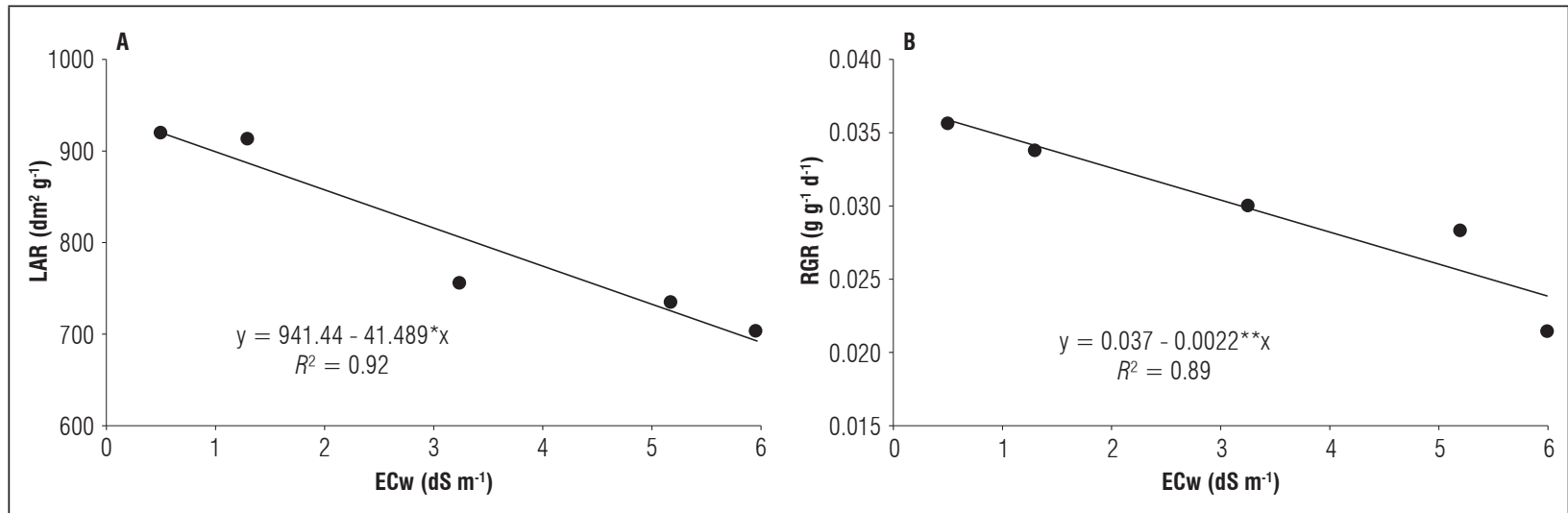

Figure 3. Leaf area ratio $(A)$ and relative growth rate $(B)$ of the radish plants as a function of the different electrical conductivities of the irrigation water (ECw). 


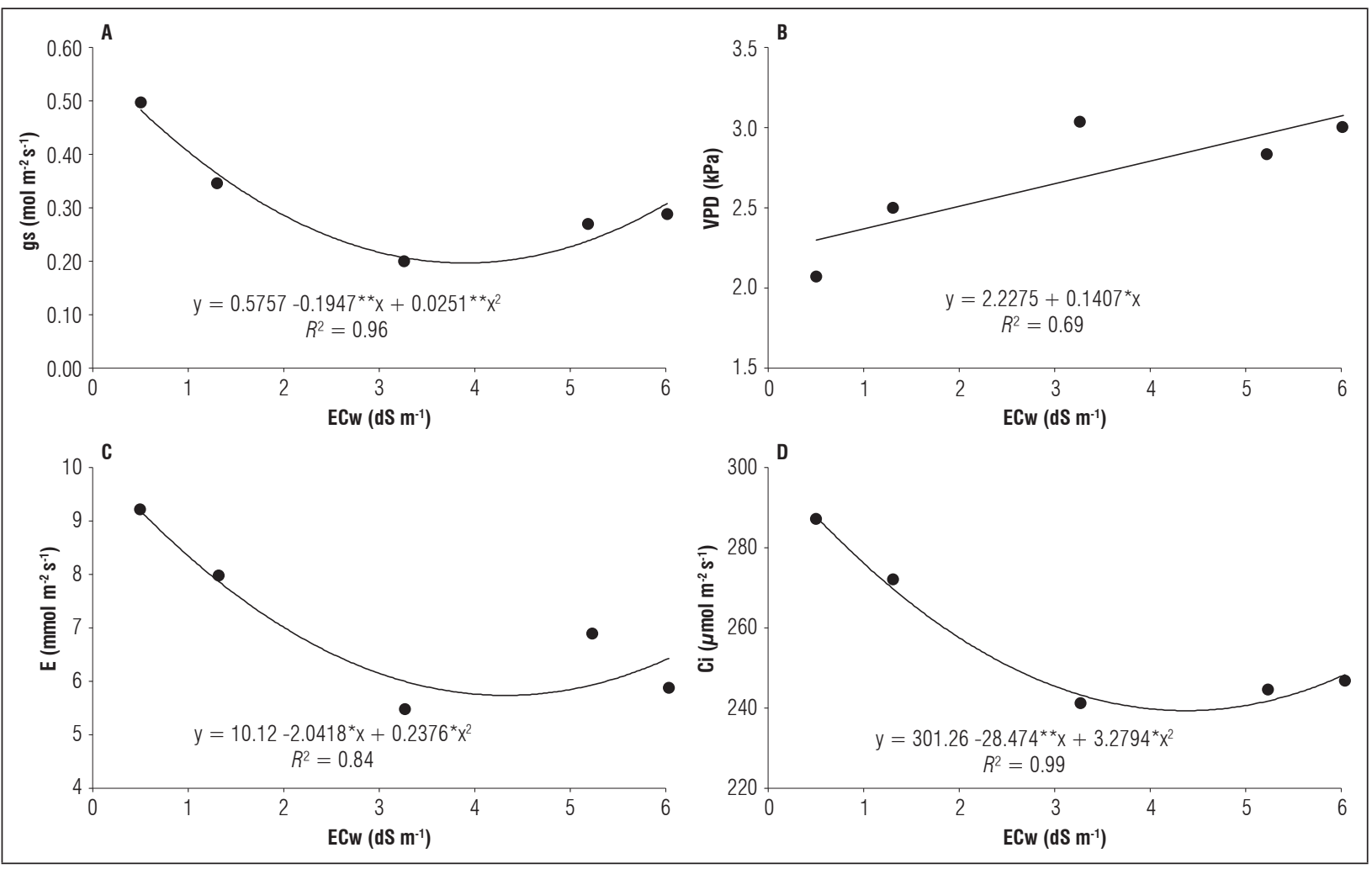

Figure 4. Stomatal conductance (gs), internal $\mathrm{CO}_{2}$ concentration (Ci), transpiration (E) and vapor pressure deficit (VPD) of the radish plants as a function of the different electrical conductivities of the irrigation water (ECw).

Ayyub et al. (2016), evaluating different radish genotypes under saline stress, emphasized that stomatal conductance decreased with an increasing salinity, where a lower stomatal condutace was observed with a conductivity of $7 \mathrm{dS} \mathrm{m}^{-1}$ and that the main effect of salinity is a reduction of photosynthetic processes. Sousa et al. (2016b), evaluating gaseous exchanges in citrus irrigated with saline waters, observed a reduction of gs, A, E and internal efficiency of carboxylation as the ECw increased from 0.6 to $3.0 \mathrm{dS} \mathrm{m}^{-1}$. Plants under saline stress also present a reduction of $\mathrm{Ci}$ because stomatal closure causes a decrease in the rate of assimilation of carbon in the leaf mesophyll (Santos and Brito, 2016). Ci is very relevant because the productivity of a plant can be understood as the product of interception of solar energy and fixed $\mathrm{CO}_{2}$, where an adequate amount of light and higher concentrations of $\mathrm{CO}_{2}$ provide higher photosynthetic rates. The stomatal closure impairs this activity, but, on the other hand, it reduces transpiration, reducing water loss in plants maintaining cellular turgescence and increasing photosynthetic efficiency (Taiz et al., 2017).
The vapor pressure deficit (VPD) was higher as the $\mathrm{ECw}$ increased from 0.5 to $6.0 \mathrm{dS} \mathrm{m}^{-1}$ (Fig. $4 \mathrm{D}$ ), ranging from 2.30 to $3.11 \mathrm{kPa}$, corresponding to an increase of $26 \%$ and evidencing that plants under salt stress are more vulnerable to a VPD, with a possible loss of water to the atmosphere.

According to Parihar et al. (2015), the water restriction caused by high salt concentrations in the soil solution causes plants to close their stomata to increase water use efficiency and reduce the loss of water to the atmosphere, thereby reducing gs, $\mathrm{E}, \mathrm{Ci}$ and A. Barboza and Teixeira Filho (2017), working with sugarcane, observed a higher gs early in the morning, when the VPD was low and the plants were hydrated, with the reverse seen in the late afternoon when the gs decreased and VPD increased.

As the gs increased, A, E, Ci also presented higher values (Fig. 5), corresponding to increases of 77.64, 58.97 and $82.24 \%$, respectively. However, there was a reduction in the WUE, corresponding to a decrease of $78.07 \%$. The variations ranged from 5.52 to 9.36 for E; 237.50 to 288.79 for $\mathrm{Ci}$ and 2.28 to 1.78 for WUE. 
According totheseresults, A, E, CiandWUEhadastrong relationship with the gs. The first three were directly proportional to the gs, and the latter were inversely proportional to the gs (Fig. 5). Under high gs conditions, $\mathrm{Ci}$ and $\mathrm{A}$ were favored by a greater assimilation of $\mathrm{CO}_{2}$, and $\mathrm{E}$ increased as a result of a greater number of open stomata, causing the plants to lose more water and consequently reducing WUE (Taiz et al., 2017).

As seen in the present study, Peloso et al. (2017) observed a directly proportional relationship between $\mathrm{A}$ and gs, where the gs increase provided higher A values in a coffee crop. Similarly, Barboza and Teixeira Filho (2017) reported that E was higher as sugarcane gs increased. Ferreira et al. (2011) also observed a directly proportional relationship between $\mathrm{Ci}$ and $\mathrm{E}$ and the gs and an inversely proportional relationship between USA and the gs in a soybean crop.

The reduction of gs is considered one of the main factors that restrict photosynthetic activity, decreasing the $\mathrm{CO}_{2}$ influx to the rubisco carboxylation sites within the chloroplasts and causing a decline in the photosynthetic rate. It also reduces $\mathrm{E}$, providing less water loss and greater WUE (Tatagiba et al., 2015).

\section{CONCLUSIONS}

The electrical conductivity of the irrigation water $(\mathrm{ECw})$ influenced the agronomic yield and gas exchange of the radish plants (Raphanus sativus L.) for gs, Ci, E and A, as a function of the gs. The foliar applications of ascorbic acid did not influence the agronomic yield or gaseous exchanges of the radish plants at the tested doses. The gs had a directly proportional relationship with $\mathrm{A}, \mathrm{E}$ and $\mathrm{Ci}$ and an inversely proportional relationship with WUE.

Conflict of interests: this manuscript was prepared and reviewed with the full participation of the authors, who declare that there exists no conflict of interest that puts at risk the validity of the presented results.

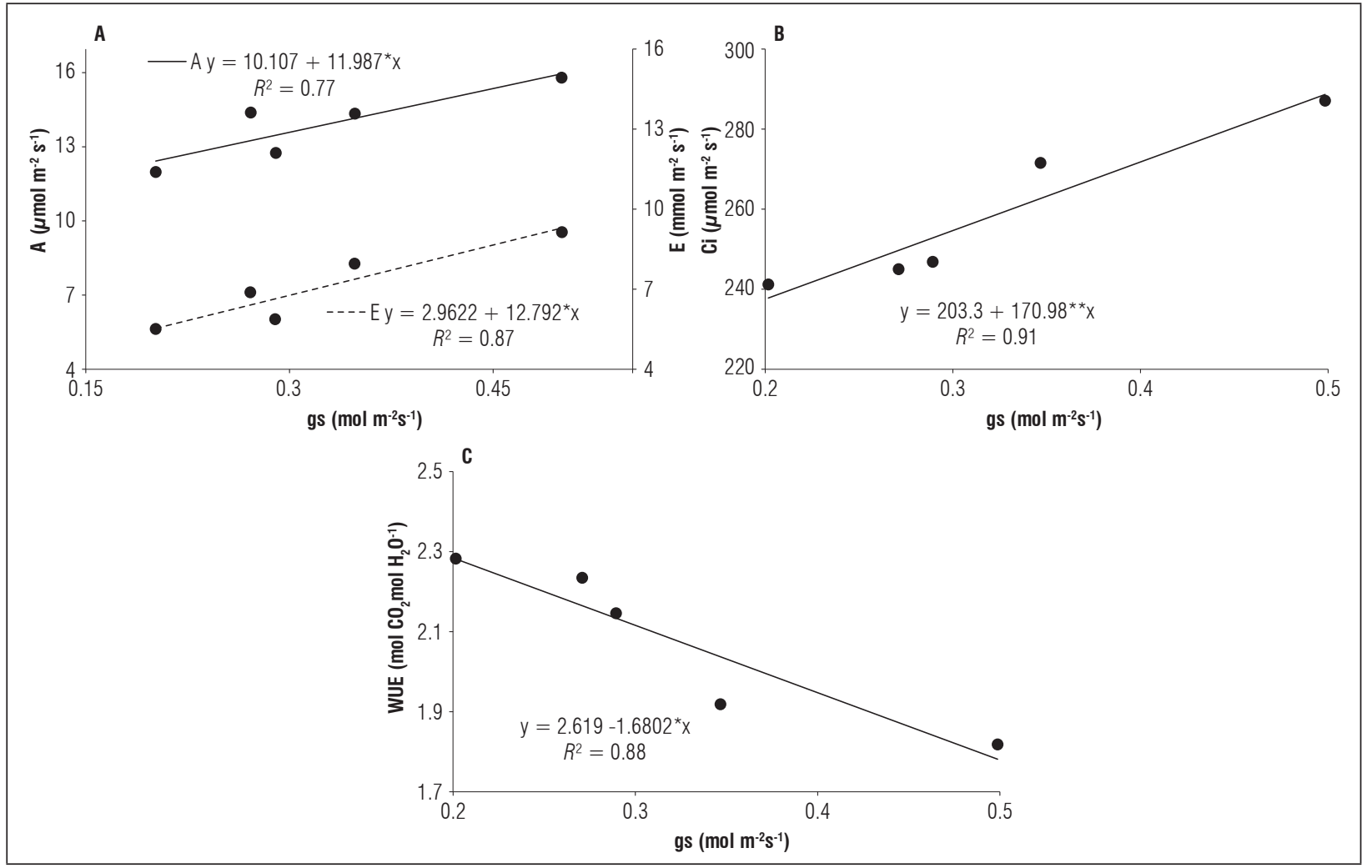

Figure 5. Net photosynthesis and transpiration (A), internal $\mathrm{CO}_{2}$ concentration (B) and water use efficiency (C) as a function of the stomatal conductance in the radish plants subjected to different electrical conductivities of the irrigation water. 


\section{BIBLIOGRAPHIC REFERENCES}

Ayyub, C.M., M.R. Shaheen, S. Raza, M.S. Yaqoob, R.W.K. Qadri, M. Azam, M.A. Ghani, I. Khan, and N. Akhtar. 2016. Evaluation of different radish (Raphanus sativus) genotypes under different saline regimes. Am. J. Plant Sci. 7(6), 894-898. Doi: 10.4236/ajps.2016.76084

Barboza, G.C. and J. Teixeira Filho. 2017. Transpiração foliar e condutância estomática da cana-de-açúcar em função do clima e disponibilidade de água. Irriga 22(4), 675-689. Doi: 10.15809/irriga.2017v22n4p675-689

Benincasa, MMP. 2003. Análise de crescimento de plantas: noções básicas. FUNEP, Jaboticabal, São Paulo, Brazil.

Bortoluzzi, A.L. and V.V.H. Alvarez. 1997. Pesquisa em casa de vegetação e em campo: matrizes experimentais. Departamento do Solo/CCA - Universidade Federal de Viçosa, Viçosa, Brazil.

Brunes, A.P., D.A.R. Fonseca, C.A. Rufino, L.C. Tavares, L.M. Tunes, and F.A. Villela. 2013. Seedling growth of white oats submitted to salt stress. Semina: Cienc. Agrár. 34(6), 3455-3462. Doi: 10.5433/1679-0359.2013v34n6Supl1p3455

Cody, R. 2015. An introduction to SAS University Edition. SAS Institute, Cary, NC.

Cunha, F.F., M.A. Castro, A.R. Godoy, F.F. Magalhães, and A.J.F. Leal. 2017. Irrigação de cultivares de rabanete em diferentes épocas de cultivo no nordeste sul-mato-grossense. Irriga 22(3), 530-546. Doi: 10.15809/ irriga.2017v22n3p530-546

Eschemback, V., M.R. Bernert, A. Jadoski, S.O. Suchoronczek, and A.S. Lima. 2014. Características da Salinidade dos solos em cultivos agrícolas no Brasil. Appl. Res. Agrotechnol. 7(3), 115-124.

Ferreira, E.A., I.A. Aspiazú, L.L. Galon, G.C. Concenço, A.F. Silva, L.A.C. Reis, and F.P. Carvalho. 2011. Características fisiológicas da soja e espécies de plantas daninhas. Rev. Tróp. - Ciênc. Agrár. Biol. 5(1), 39-47.

Gul, H., R. Ahmad, and M. Hamayun. 2015. Impact of exogenously applied ascorbic acid on growth, some biochemical constituents and ionic composition of guar (Cymopsis Tetragonoloba) subjected to salinity stress. Pakhtunkhwa J. Life Sci. 3(1-2), 22-40.

Hameed, A., S. Gulzar, I. Aziz, T. Hussain, B. Gul, and M.A. Khan. 2015. Effects of salinity and ascorbic acid on growth, water status and antioxidant system in a perennial halophyte. AoB Plants 7, plv004. Doi: 10.1093/ aobpla/plv004

Lanna, N.B.L., P.N.L. Silva, L.F. Colombari, C.V. Corrêa, and A.I.I. Cardoso. 2018. Residual effect of organic fertilization on radish production. Hort. Bras. 36(1), 47-53. Doi: 10.1590/s0102-053620180108

Lima, G.S., H.R. Gheyi, R.G. Nobre, L.A.A. Soares, P.D. Fernandes, and G.F. Furtado. 2017. Trocas gasosas, pigmentos cloroplastídicos e dano celular na mamoneira sob diferentes composições catiônica da água. Rev. Irriga 22(4), 757-774. Doi: 10.15809/ irriga.2017v22n4p757-774

Medeiros, J.F. 1992. Qualidade da água de irrigação utilizada nas propriedades assistidas pelo "GAT" nos Estados do RN, PB, CE e avaliação da salinidade dos solos. 1992. 173f. MSc thesis. University of Campina Grande, Campina Grande, Brazil.

Mekawy, A.M., D.V. Assaha, H. Yahagi, Y. Tada, A. Ueda, and H. Saneoka. 2015. Growth, physiological adaptation, and gene expression analysis of two Egyptian rice cultivars under salt stress. Plant Physiol. Biochem. 87, 17-25. Doi: 10.1016/j.plaphy.2014.12.007

Oliveira, A.M.P., A.D. Oliveira, N.S. Dias, M. Freitas, and K.B. Silva. 2012. Cultivo de rabanete irrigado com água salina. Rev. Verde Agroecol. Desenvolv. Sustent. 7(4), $1-5$.

Oliveira, F.R.A., F.A. Oliveira, J.F. Medeiros, V.F.L. Sousa, and A.G. Freire. 2010. Interação entre salinidade e fósforo na cultura do rabanete. Rev. Ciênc. Agron. 41(4), 519-526. Doi: 10.1590/S1806-66902010000400003

Parihar, P., S. Singh, R. Singh, V.P. Singh, and S.M. Prasad. 2015. Effect of salinity stress on plants and its tolerance strategies: a review. Environ. Sci. Pollut. Res. 22(6), 4056-4075. Doi: 10.1007/s11356-014-3739-1

Peloso, A.F., S.D. Tatagiba, E.F. Reis, J.E.M. Pezzopane, and J.F.T. Amaral. 2017. Limitações fotossintéticas em folhas de cafeeiro arábica promovidas pelo déficit hídrico. Coffee Sci. 12(3), 389-399.

Santos, M.R. and C.F.B. Brito. 2016. Irrigação com água salina, opção agrícola consciente. Rev. Agrotecnol 7(1), 33-41. Doi: 10.12971/2179-5959/agrotecnologia. v7n1p33-41

Santos, R.A., P.T. Carneiro, V.R. Santos, L.C. Costa, C.G. Santos, and A.L. Santos Neto. 2014. Crescimento de leguminosas utilizadas na adubação verde em diferentes níveis de sais na água de irrigação. Rev. Bras. Eng. Agric. Ambient. 18(12), 1255-1261. Doi: 10.1590/18071929/agriambi.v18n12p1255-1261

Santos, G.P., L.F. Cavalcante, J.A.M. Nascimento, M.E.B. Brito, T.A.G. Dantas, and J.A. Barbosa. 2012. Produção de pitangueira utilizando adubação organomineral e irrigação com água salina. Irriga 17(4), 510-522. Doi: 10.15809/irriga.2012v17n4p510

Santos, D.P., C.S. Santos, P.F. Silva, M.P.M.A. Pinheiro, and J.C. Santos. 2016. Crescimento e fitomassa da beterraba sob irrigação suplementar com água de diferentes concentrações salinas. Rev. Ceres 63(4), 509-516. Doi: 10.1590/0034-737X201663040011

Santos, V.M., L.L. Silva, P.C. Ramos, S.C. Siebeneichler, D.P. Cardoso, and A.R. Silva. 2017. Análise do crescimento de rabanete em função de períodos de convivência 
com plantas daninhas. Rev. Bras. Agropec. Sustent. 5(1), 121-129.

Silva, A.O., T.M. Soares, Ê.F.F. Silva, A.N. Santos, and A.E. Klar. 2012. Consumo hídrico da rúcula em cultivo hidropônico NFT utilizando rejeitos de dessalinizador em Ibimirim-PE. Irriga 17(1), 114-125. Doi: 10.15809/ irriga.2012v17n1p114

Sousa, J.R.M., H.R. Gheyi, M.E.B. Brito, D.A. Xavier, and G.F. Furtado. 2016b. Impact of saline conditions and nitrogen fertilization on citrus production and gas exchanges. Rev. Caatinga 29(2), 415-424. Doi: 10.1590/1983-21252016v29n218rc

Sousa, G.G., V.S. Rodrigues, T.V.A. Viana, G.L. Silva, M.O. Rebouças Neto, and B.M. Azevedo. 2016a. Irrigação com água salobra na cultura do rabanete em solo com fertilizantes orgânicos. Rev. Bras. Agric. Irrigada 10(6), 1065-1074. Doi: 10.15809/irriga.2012v17n1p114

Srivastava, V., R.P. Singh, P. Singh, and K. Verna. 2016. Varietal germination, biochemical and growth responses of radish (Raphanus sativus L.) grown under different level of salt stress. In: Ashraf, M.A. and W.S. Aqma (eds.). International Conference on Clean Water, Air \& Soil (CleanWAS 2015). Vol: Envionmental Conservation, Clean Water, Air \& Soil (CleanWas), IWA Publishing, London.

Sun, X., L. Xu, Y. Wang, X. Luo, X. Zhu, K.B. Kinuthia, S. Nie, H. Feng, C. Li, and L. Liu. 2016. Transcriptome -based gene expression profiling identifies differentially expressed genes critical for salt stress response in radish (Raphanus sativus L.). Plant Cell Rep. 35(2), 329-346. Doi: 10.1007/s00299-015-1887-5

Taiz, L., E. Zeiger, I.M. Moller, and A. Murphy. 2017. Fisiologia e desenvolvimento vegetal. $6^{\text {th }}$ ed. Artmed Editora, Porto Alegre, Brazil.

Tatagiba, S.D., J.E.M. Pezzopane, and E.F. Reis. 2015. Fotossíntese em Eucalyptus sob diferentes condições edafoclimáticas. Eng. Agric. 23(4), 336-345. Doi: 10.13083/1414-3984/reveng.v23n4p336-345

Witkowski, E.T.F. and B.B. Lamont. 1991. Leaf specific mass confounds leaf density and thickness. Oecologia 88(4), 486-493. Doi: 10.1007/BF00317710 